\title{
Migrant Health Care Services Provided by Public Sector in Turkey
}

\author{
Memet Taşkın Egici
}

Department of Family Medicine, Haydarpaşa Numune Training and Research Hospital, Health Sciences University, İstanbul, Turkey

\section{ABSTRACT}

Persons who take refuge into other countries for various reasons are defined as migrants, asylum seekers or refugees according to their legal status. Although the legal status is different, the social problems are similar. Asylum seekers and refugees are among the most vulnerable groups in terms of health as they have challenging living conditions, housing and nutrition-related problems as well as difficulties in communication and transport and in accessing to health care and social support services. Our country is constantly facing immigration because of its geographical location, social structure and historical background. Due to the civil war in Syria, our country which has been facing massive migration since 2011. According to 2017 data from United Nations Refugee Organisation, Turkey hosts the largest number of refugees granted 'temporary protection'. According to Disaster and Emergency Management Authority's reports, the current number of Syrians registered in Turkey is 3.545.293. Turkey also hosts more than 300.000 people from other nationalities. Although huge migrant health problem, a big effort is made to provide services and these very comprehensive preventive and curative health care services are largely provided by the Ministry of Health. The general coordination of disasters and emergencies is carried out by the Disaster and Emergency Management Authority. Health care services are carried out under the coordination of the Directorate General of Migration Management of the Ministry of Interior and operated by Presidency of Migration Health Department under the General Directorate of Public Health of $\mathrm{MoH}$. In order to prevent any adverse impact on the health status of both the migrants and the Turkish people, studies on infectious and non-infectious diseases should continue and the registration and surveillance systems should be reviewed. The number of Migrant Health Care Centers should be increased, communication and guidance facilities should be established and cooperation with NGOs should be improved.

Please cite this article as: Egici MT. Migrant Health Care Services Provided By Public Sector in Turkey. Anatol J Family Med 2019;2(1):7-12.

Address for correspondence: Dr. Memet Taşkın Egici. Sağlık Bilimleri Üniversitesi, Haydarpaşa Numune Eğitim ve Araştırma Hastanesi, Aile Hekimliği Kliniği, İstanbul, Turkey

Phone: +902165423232

E-mail: megici@gmail.com

Received Date: 25.11.2018

Accepted Date: 22.12.2018

Published online: 30.04 .2019

CCopyright 2019 by Turkish Foundation of Family Medicine - Available online at www.anatoljfm.org
Keywords: Asylum seeker, community health service, human migrations, preventive health service, public health, refugees

\section{INTRODUCTION}

People who leave their countries, thinking that they are discriminated on the grounds of their social, political, religious, racial or national identity and demand international protection by seeking asylum to another country due to war, internal conflict, attack, natural disasters etc. are called asylum seekers. If such demand for protection of the asylum-seeker is granted by the country of refuge, this person is called a refugee. Migrants are defined as people who settle in another country to live in better economic and social conditions. ${ }^{[1,2]}$

Our country faces extensive social migration due to its geographical position, social structure and historical background, and is a country of refuge for asylum-seekers, refugees and migrants who are forced to leave their countries due to various reasons. In 1968, the Republic of Turkey ratified the "Geneva Convention relating to the Status of Refugees" and the comple- 
mentary "New York Protocol concerning the Legal Status of Refugees dated 1967" by making two reservations, i.e. "No provision of this Convention may be interpreted as granting to refugees' greater rights than those accorded to Turkish citizens in Turkey" and "in the context of seeking asylum from Europe", which is the geographical limitation reservation. In other words, pursuant to this geographical reservation, Turkey grants to people who come from the European countries the right to become a refugee and to those who come from non-European countries the right to become an asylum seeker. ${ }^{[1,2]}$ According to the data from the United Nations Refugee Organisation (UNHCR) for 2017, people who seek international protection in Turkey, which hosts the largest number of refugees in the world, are granted 'temporary protection'. (Temporary Protection refers to the protection granted to foreigners who are forced to leave their country, cannot return to their country, arrive in masses in our borders in order to find emergency and temporary protection or come to our borders or cross our borders individually during this period of mass influx and whose demand for international protection cannot be evaluated individually). ${ }^{[2]}$

According to Disaster and Emergency Management Authority (AFAD)'s reports, the current number of Syrians registered in Turkey is 3.545.293, about 200 thousand of whom are accommodating in temporary accommodation centers, i.e. they reached $4.39 \%$ of the population in Turkey. Turkey also hosts more than 300.000 people from other nationalities. ${ }^{[3,4]}$

\section{Migrants and Health Problems}

Accommodation, security, nutrition, education and health care services are the primary supports offered to asylum seekers in Turkey. Large population movements due to war, internal conflict and terrorism cause grave problems in health care as well as social and psychological difficulties. Such social incidents are defined as complex humanitarian emergencies, complex disasters or humanitarian emergencies. ${ }^{[5]}$

Migrants, refugees and asylum seekers undergo individual and family separation and deprivation and suffer from physical and mental traumas. Asylum seekers and refugees, in particular, are among the most vulnerable groups in terms of health as they have challenging living conditions, housing and nutrition-related problems, difficulty in accessing to health care and social support services, difficulties in communication and transport, and violence.

It is particularly important for migrants to benefit from preventive and curative health care services, as they have the potential to directly affect the health status of the citi- zens where they go. The most prominent cases among the health-related problems include: ${ }^{[6-8]}$

- Infectious Diseases

- Nutrition disorders,

- Growth and development deficiencies in children

- Anemia

- Infectious diseases such as diarrhea, measles, malaria, respiratory infections etc.

- Physical violence and associated injuries

- Sexual harassment

- Sexually transmitted infections including HIV/AIDS

- Unintended pregnancies, high-risk pregnancies

- Abortions, birth complications

- Chronic diseases and complications,

- Drawbacks in chronic patient control

- Psychological problems such as depression, anxiety disorders, sleep disorders and post-traumatic stress disorder

- Aggravation of any existing health problems of an individual

- Trauma, hypothermia, burn

- Gastrointestinal diseases

- Drug addiction, alcoholism

- Dental health problems

\section{Health Care Services Provided to Migrants in Turkey}

The general coordination of disasters and emergencies is carried out by the AFAD. In accordance with the Law No. 5510 regarding immigrant health and Law No. 6458 concerning Foreigners and International Protection and the Regulation on Temporary Protection, the coordination of health care services that are carried out under the coordination of the Ministry of Interior the Directorate General of Migration Management. At the level of Ministry of Health is assumed by Presidency of Migration Health Department that operates under the General Directorate of Public Health and their coordination and execution is assumed by Directorate of Health at the provincial level. These legal bases are chronologically as follows: $:^{[1,9-12]}$

- Prime Ministry AFAD Regulation (19/02/2011)

- Law on Foreigners and International Protection (04/04/2013)

- Regulation on Temporary Protection (22/10/2014)

- Circular on the Execution of Services for Foreigners under Temporary Protection (18/12/2014)

- The Decree Law on Iraqi entering our country after 01/05/2014 (26/01/2015) 
- Principles of Health Services to be Provided to Those under Temporary Protection (25/03/2015)

- The Protocol between AFAD and Ministry of Health dated $2015(01 / 07 / 2015)$

- AFAD-Circular on the Health Care and Other Services of Syrian Guests (12/10/2015)

- Directive on Migrant Health Centers/Units (03/09/2015)

- Principles on Amendments to Principles for Health Care Services to be Provided to Those under Temporary Protection (04/11/2015)

- The Protocol between AFAD and Ministry of Health dated 2016 (01/01/2016).

Health care services are largely executed by the Ministry of Health. The share of private sector is only $1.5-3 \%$. Therefore, the health of migrants will be the focus in the scope of public health. Likewise, since Syrians constitute the vast majority of immigrants, the services given to Syrians will be examined mainly. Health care services to Syrian asylium seekers provided in Turkey is summarized in Table $1 .{ }^{[13]}$ Public health care services in our country are offered to Syrians under three categories: 112 Emergency Health Services, Basic and Preventive Health Services, Secondary and Tertiary Health Services.

The delivery of health care service starts at the border, and the people who are injured or emergency patients are transported to hospitals by 112 emergency medical teams and all necessary treatments are made. All people crossing the border are screened for general health and the required health services are provided along with fresh water and food. Syndromic surveillance is performed for gastrointestinal tract infections. Children aged below 15, who are considered to be a risk group, and women aged 15-49 are vaccinated. In this context, children aged 0-15 were administered oral polio vaccine, children aged 9 months- 15 years were administered measles-mumps-rubella vaccine, children aged below 7 were administered DTaB-IPA-Hib and children aged 7-12 were administered DTaB-IPA and women aged 15-49 were administered Diphtheria-Tetanus vaccines. ${ }^{[1,6,13]}$

Health care services are provided within the framework of the "Principles regarding the Health Care Services to be given to those under Temporary Protected" dated 25/03/2015 and numbered 2875, prepared and published by our Ministry pursuant to the Regulation on Temporary Protection of

Table 1. Health services provided to temporarily Syrian
asylum seeker in Turkey $(2011-2017)$
\begin{tabular}{lllllc} 
Polyclinic & Inpatient & Childbirth & Surgery & Vaccination dose \\
\hline 31.449 .800 & 1.326 .849 & 276.158 & 1.112 .858 & 3.215 .128 \\
\hline
\end{tabular}

the Syrians entering our country and other relevant legislation. ${ }^{[9,10]}$ Accordingly,

- Syrians, who are recorded in Turkey and are granted a temporary identification number, may benefit free of charge from emergency medical, protective and primary health care services and all curative health care services in the provinces where they reside within the scope of Communiqué on Health Care Practices. Those who are not assigned a temporary identification number are provided with services such as the fight against infectious diseases, immunization and emergency health services within the framework of the "Regulation on Temporary Protection".

- Syrians who are under temporary protection can apply directly to the Ministry of Health institutions without any referral and they can apply directly to University hospitals and private hospitals only in case of emergencies. Referral first to university hospitals, and if this is not possible, to private hospitals is carried out within the scope of emergency medical services and intensive care unit services and burn and cancer treatments.

- Health care services are provided by 112 emergency health teams, Community Health Center staff as well as hospital staff in more crowded centers in Temporary Accommodation Centers (Table 2) and by Community Health Centers and affiliated Units (Migrant Health Centers, Fight against Tuberculosis Units, etc.), Family Health Care Centers (FHCs), Hospitals (public, private, university) and Temporary Voluntary Health Facilities outside the temporary accommodation centers. ${ }^{[3,9,10,14]}$

\section{Migration Health Centers (MHCs)}

Migrant Health Centers (MHCs) are established in areas, where Syrians densely live, as a supplementary unit of community health center of the district to provide protective and basic health care services to Syrians in our country in a more effective and efficient manner, to overcome the problems arising from the language and culture barrier and to increase their access to health care services. MHCs comprise of migrant health units that include a physician and assistant health professionals who serve every 4.000 people in average and they are stipulated to meet the physical and technical requirements defined for FHCs. In

Table 2. The number of employees in temporary accommodation centres

Turkish Turkish health Syrian Syrian health physicians care professionals physicians care professionals

156

186

109

137 
MHCs, bilingual (Arabic-Turkish) patient guidance staff and support services personnel are employed. Date on primary health care services provided to Syrians under temporary protection are recorded under "Inspection Information Management System". $[1,14,15]$

\section{Strengthened Migrant Health Centers (Strengthened MHCs)}

In settlement areas that are located remotely to public hospitals and where more than 20.000 Syrians reside, internal diseases, pediatrics, maternal-childbirth, oral-dental health and psychosocial support services are provided in addition to primary health care services and Strengthened MHCs that are supported by imaging units and basic service laboratories are established so as to increase access and reduce the burden on hospitals.

Primary health care services provided are funded from the General Budget; the services offered by universities and private hospitals are funded by "Directorate General of Migration Management" if they meet proper procedures and 112 emergency health services and secondary and tertiary health services are also funded by the abovementioned directorate. Costs of medicines used for outpatient treatment and medical equipment (orthesis, prosthesis, etc.) are also paid by the Directorate General of Migration Management. ${ }^{[14,15]}$

\section{Polyclinic for Foreigners}

Polyclinics for Foreigners are established under the District Health Directorates/ Community Health Centers, provided that one clinic is available in every district, in order to provide and coordinate primary health care services to people under temporary protection status and migrants in other statuses in all provinces, who are resident in areas where MHCs are not planned to be opened. ${ }^{[15]}$

In the framework of "Readmission Agreement" signed between Turkey and the European Union on October $15^{\text {th }}$, 2015, the "Project for Improving the Health Status of Syrian population under Temporary Protection and Services provided by the Republic of Turkey (SIHHAT)" was adopted. Within the scope of the project, activities are planned for the development of primary and secondary health care services for Syrians and for increasing health literacy. Other activities are carried out to support MHCs, establish new MHCs where needed and to hire Syrian health professionals in order to deliver services in these centers. In the same scope, trainings are given where family medicine academicians play a role in order to meet the need for interpreters and guidance of health institutions. The project duration is 36 months and the action plan is planned to be completed on December $1^{\text {st }}, 2019 .{ }^{[14,15]}$
In 27 provinces, 527 migrant health units were opened within 154 migrant health centers and they continue their operations. It is planned to extend the MHCs to 30 provinces, to provide services with 805 migrant health units in $180 \mathrm{mi}-$ grant health centers to be established in these provinces and to build 42 out of these centers as Strengthened MHCs. ${ }^{[14,15]}$

\section{Health Care Services Provided by Non-Governmental Organizations}

Within the framework of the "Principles on Health Care Services to be provided to those under Temporary Protection", Non-Governmental Organizations (NGOs) may open "Voluntary Health Facilities" that are operated on a voluntary basis and with a 6-month license to provide free of charge health services to those under temporary protection. In these facilities, services are provided under the responsibility of a physician and nurse who are authorized to carry out their professions in Turkey in settlement areas approved by the Ministry and outpatient and treatment services and rehabilitation services are included in the services to be delivered. In our country, 13 voluntary health facilities operate for this purpose in 5 provinces. ${ }^{[13]}$

\section{MHCs Services Provided to People of Other Nationalities apart from Syrians}

Pursuant to the decision of the Council of Ministers, Iraqis, who have entered into our country after 01/05/2014 and are holders of humanitarian residence permit, are provided with health care services that are also provided to those under temporary protection status. Health care services of Meshketian Turk families are also provided by the units of our Ministry and their other needs are met by the provincial governorships.

\section{Fight against Infectious Diseases and Vaccination Activities}

Syrian children in our country are vaccinated in accordance with the vaccination schedule applied in our country. In addition, supplementary and supportive activities are carried out from the beginning of the migration, in the studies conducted by the Ministry of Health on the possible infectious diseases that are likely to be seen in the Syrians. Between 2012-2016, a total of 168.137 blood smears were collected from the Syrians and any malaria case was not detected. Seven thousand and 794 Cutaneous Leishmaniasis cases and 935 tuberculosis cases were identified and the treatment was started. ${ }^{[6]}$

Infections that may be the most common problem with migration are Tuberculosis HIV/AIDS, Hepatitis B, Hepatitis C, vaccine preventable diseases, parasitic diseases, water and nutrient-transmitted infections. The World Health Organization makes different recommendations instead of rou- 
tine mandatory screening: ${ }^{[6,16]}$

- Regular health check

- Providing access to health care for diseases requiring protection, appropriate triage

- Meeting the health requirements of vulnerable groups

- Vaccination programs

- A good preparation program

- Medium- and long-term approach programs

- Increasing capacity

- Surveillance - Strengthening the early warning system

- Industrial and international cooperation

- Observing human rights, not being discriminative or exclusionary.

Ongoing/Potential Problems $s^{[0,7,11,12,15]}$

- Main social and economic problems arising from migration

- Negative reflections on our country's health economy

- Psychological problems

- Communication problem due to the language barrier

- Failure to access the appointment system

- Difficulties in following the vaccine-preventable diseases

- Burnout experienced by the health personnel from time to time

- Health problems caused by housing and nutrition difficulties

- Challenge in fighting against non-infectious diseases

- Deficiencies in maternal and child health

\section{CONCLUSION}

The Republic of Turkey faces a huge migrant health problem. Efforts are made to provide health care services to the extent of the possibilities. In order to prevent any adverse impact on the health status of both the migrants and the Turkish people, studies on infectious and noninfectious diseases should continue and the registration and surveillance systems should be reviewed. As the problem will can continue long time, the number of MHCs should be increased, communication and guidance facilities should be established and further cooperation with NGOs should be made. Of course, the main solution is the finalisation of war and conflicts, which are the biggest cause of migration.

\section{Disclosures}

This review presented as a conference paper at the $12^{\text {th }}$ Family Medicine Autumn School, Antalya.
Peer-review: Externally peer-reviewed.

Conflict of Interest: None declared.

Funding source: There is no funding in this article.

\section{REFERENCES}

1. Gültaç A, Yalçın Balçık P. Suriyeli Sığınmacılara Yönelik Sağlık Politikaları. Sak Med J 2018;8(2):193-204. [CrossRef]

2. Göç İdaresi Genel Müdürlüğü. 2016 Türkiye Göç Raporu [Internet].Available from: http://www.goc.gov.tr/files/files/ 2016 yiik_goc_raporu_haziran.pdf. Access Date: 10 epS 2018.

3. Başbakanlık AFAD, 13.08.2018 Suriye GBM Bilgi Notu.pdf [Internet]. Available from: https://www.afad.gov.tr/upload / Node/2374/files/13_08_2018_Suriye_GBM_Bilgi_Notu.pdf. Access Date: 14 Sep 2018.

4. Aydın B, LeblebiciY, Egici MT, Bektemur G. Geçici Sığınmacıların Sağlık Hizmetlerinden Yararlanmasında Yaşanan Sorunlar ve Çözüm Önerileri (İstanbul Beyoğlu Kamu Hastaneleri Birliği Örneği). Available from: http://www.dunyamuslumansaglik. org/dosya/1.pdf. Access Date:10 Sep 2018.

5. Yavuz Ö. Türkiyedeki Suriyeli Mültecilere Yapılan Sağlık Yardımlarının Yasal ve Etik Temelleri/The Legal and Ethical Foundations of Health Assistanceso t Syrian Refugeesn i Turkey. Mustafa Kemal Üniversitesi Sos Bilim Enstitüsü Derg [Internet] 2015;12(30).

6. Tülek DN. Göçmenler ve Enfeksiyonlar. XVIII.KLIMiK Kongresi, 0172 Antalya; 2017 [Internet]. Available from: https://www.klimik.org.tr/wp-content/uploads/2017/05/ G\%C3\%B6\%C3\%A7menler-ve-\%C4\%B0nfeks\%C4\%B0yonlarNecla-T\%C3\%9CLEK.pdf Access Date:10 Sep 2018.

7. Karadağ Ö, Altıntaş KH. Mülteciler ve Sağlık. TAF Prev Med Bull 2010;9(1):55-62.

8. Çallı M. Türkiye'de Mültecilerin ve Sığınmacıların Sağlık Hakkı. İş ve Hayat 2016;2:131-54.

9. Geçici Koruma Altına Alınanlara Verilecek Sağlık Hizmetlerine Dair Esaslar Hakkında 25.03.2015 tarihli ve 39942531 sayılı Yönerge. Sağlık Bakanlığı [Internet]Available. from: https:// www.saglik.gov.tr/TR,11288/gecici-koruma-altina-alinanlara-verilecek-saglik-hizmetlerine-dair-esaslar-hakkinda22102014-tarihli-ve-29153-sayili-yonerge.html. Access Date: 10 Sep 2018.

10. Göç İdaresi Genel Müdürlüğü. Geçici Koruma Yönetmeliği 2014 [Internet]. Available from: http:www.goc.gov.tr/files/ files/03052014_6883.pdf. Access Date:22 Oct 2014.

11. Egici MT. Geçici Sığınmacılar; Kamu Hastanelerinde Yaşanan Sıkıntılar Ve Çözüm Önerileri. Ülkemize Sığınan Yabancıların Sağlık Hakları 2015 [Internet]. Available from: http://www. istanbulsaglik.gov.tr/w/sb/saggel/belge/Uzm_D r_Mehmet_ Taskin_EGICl.pdf. Access Date:10 Sep 2018.

12. Selenay E. Sağlık Hizmetlerine Erişimin Yasal Dayanağı. Ülkemize Sığınan Yabancıların Sağlık Hakları 2105 [Internet]. Available from: https://dosyaism.saglik.gov.tr/Eklenti/217 99,ave- 
lifselenaypdf.pdf?0. Access Date:10 Sep 2018.

13. Türkiye'deki Suriyeliler - Özel Rapor [Internet]. Available from: https://www.ombudsman.gov.tr/ suriyeliler/rapor. html\#p=2. Access Date:02 Dec 2018.

14. Sihhat Project [Internet]. Available from: http:// www. sihhatproject.org/. Access Date:14 Sep 2018.

15. Öztaş D. Göç ve Kadın. Multi-disipliner Göç ve Sağlık Sempozyumu, Ankara Yıldırım Beyazıt Üniversitesi 2018 Ankara [Inter- net]. Available from: https://www.tuseb.gov.tr/enstitu/tacese/ yuklemeler/ekitap/Kriz/goc_ve_kadin_yrd_doc_dr_dilek_oztas.pptx. Access Date:10 Sep 2018.

16. Migration and health: key issues 2018 [Internet]. Available from: http://www.euro.who.int/en/health-topics/health-determinants/migration-and-health/migrant-health-in-the-european-region/migration-and-health-key-issues. Access Date: 14 Sep 2018. 